\title{
A COMPREHENSIVE SEDIMENT BUDGET FOR THE MISSISSIPPI BARRIER ISLANDS
}

\author{
D.J.R. Walstra ${ }^{1,2}$, J.H. de Vroeg ${ }^{1}$, J.S.M. van Thiel de Vries ${ }^{1,2}$, C. Swinkels ${ }^{1}$, A.P. \\ Luijendijk $^{1,2}$, W.P. de Boer ${ }^{1}$, R. Hoekstra ${ }^{1}$, B. Hoonhout ${ }^{1}$, J. Henrotte ${ }^{3}$, T. Smolders ${ }^{3}$, F. \\ Dekker $^{3}$ and E. Godsey ${ }^{4}$
}

\begin{abstract}
In order to conceive any realistic plan for post-Katrina island restoration, it is necessary to understand the physical processes that move sand along the littoral drift zone off the coast of Mississippi. This littoral zone influences the character of the Mississippi barrier islands as they exist in an ever changing cycle. To help in this understanding, a sediment transport model was conducted to establish a current sediment budget for the islands. This study evaluated the existing regional sediment transport magnitudes and directions for the Mississippi and Alabama barrier islands fronting Mississippi Sound including daily conditions and hurricanes. A method was developed to incorporate all relevant hurricanes from 1917 to 2010 in the analysis. For the long term average net longshore transport along the southern shorelines of the barriers (i.e. exposed to the Gulf of Mexico), the contribution of year-averaged conditions and hurricanes are of similar order of magnitude, although the mean annual percentage occurrence of hurricanes is no more than about 3\%. Along the northern shores (Mississippi Sound side) the transport is considerably smaller and the contributions of cold fronts and hurricanes to the sediment transports are more or less equal. For the year-averaged conditions (excluding hurricanes) a westward directed net transport is found. The net effect of the historic hurricanes is also westward in direction. However, for individual hurricanes (e.g. Camille and Katrina) the net transport along Ship Island can be directed eastward due to the dominance of ebb flows after the eye of the hurricane had passed.
\end{abstract}

Keywords: sediment budget; Mississippi; barrier islands; transport modeling; Delft3D; MsCIP

\section{INTRODUCTION}

\section{Study Objective}

The main goal of the restoration of the barrier islands in the Mississippi Coastal Improvements Program (MsCIP) is to restore the sediment budget, including littoral zone geologic processes around Ship, Horn, and Petit Bois islands as close to their natural state as possible. The restoration effort seeks to return sediment into the system within the barrier islands to pre-Hurricane Camille conditions as much as possible given the realities of navigation channel dredging, climate change (sea level rise, increased frequency of storms, etc.) and other anthropogenic activities. The scale of the restoration is based on adding approximately the same volume of sand to the system that has been removed over the past decades (upwards of approximately $22 \mathrm{Mcy}$, see USACE, 2009a,b) due to (maintenance) dredging. More recent MsCIP studies by Byrnes et al. (2012), which considered both the volume of sediment removed from maintenance dredging and associated placement of dredged sediment within the system indicates that approximately 13.1 Mcy has been removed from the littoral system of the barrier islands. Restoring the Mississippi barrier islands to a condition similar to the natural system that functioned before human intervention (generally defined as the pre-Camille conditions) offers the best opportunity to ensure the long-term viability of these islands. A sketch of the Comprehensive Coastal Improvement Program is shown in Figure 1. An overview of all barrier islands, passes, navigation channels and ports in the study area is given in Figure 2. The proposed main island restoration project involves reconnecting East and West Ship Island and filling Camille Cut with about 15 Mcy of sand.

However, evaluation of the restoration efforts at Ship Island starts with a sound understanding of the observed morphological developments and the associated sediment budget of the morphological system to which Ship Island belongs and is the primary topic of this paper. In the present study, the previous work (Byrnes et al., 2012; Rosati et al., 2009) in which this morphological cell is bounded in the East by the Fort Morgan Peninsula and in the West by Cat island is followed (here referred to as the Mississippi Coastal Cell or MCC).

\footnotetext{
${ }^{1}$ Deltares, Hydraulic Engineering, PO Box 177, 2600 MH, Delft, The Netherlands. dirkjan.walstra@deltares.nl

2 Delft University of Technology, Faculty of Civil engineering and Geosciences, Section Hydraulic Engineering, PO Box 5048, 2600 GA, Delft, The Netherlands.

3 Royal HaskoningDHV, PO Box 1132, 3800 BC, Amersfoort, The Netherlands.

${ }^{4}$ U.S. Army Corps of Engineers, Mobile District, PO Box 2288, Mobile, AL 36628-0001, USA.
} 
Approach

A cascade of coupled models has been set-up which at the largest scale considers the Gulf of Mexico to represent hurricane and tidal forcing and on the smallest scale allows us to evaluate restoration alternatives at Ship Island. The derivation of the comprehensive sediment budget is based on a Delft3D model (Lesser et al., 2004; Van Rijn et al., 2007) of intermediate scale covering the MCC including wind, wave and river discharge forcing conditions. In order to evaluate the longevity of the restoration alternatives under averaged and hurricane conditions both contributions in the sediment budget derivation were considered. The averaged wave conditions were derived by removing all named events (i.e. tropical storms and hurricanes) from the European Center for Medium-Range Weather Forecasts (ECMWF) data covering the 1989-2010 period. With a bin size of $0.5 \mathrm{~m}$ for the wave height and bin sizes varying between $10^{\circ}$ and $30^{\circ}$ for the wave direction 139 "averaged" wave conditions result. For each of the "averaged" wave conditions, the sediment transport was computed for the MCC-model domain combined with a representative "morphological" tide resulting in a tideaveraged sediment transport field. The transport fields, scaled with the waves percentage of occurrence, were integrated to yield an annual sediment transport.

To be consistent with Byrnes et al. (2012) who studied the Mississippi coastal system based on observed island changes for the period from 1917 to 2010, the hurricane hindcast encompasses the same period. By considering all categories 4 and 5 hurricanes that have occurred in the Gulf of Mexico and the hurricanes and tropical storms with wind speeds exceeding $39 \mathrm{mph}$ which made landfall within $500 \mathrm{~km}$ of Ship Island 208 hurricanes remain. These hurricanes are imposed on the large-scale models to estimate their contribution to the sediment budget by applying the CERC transport formula as a proxy for their transport potential.
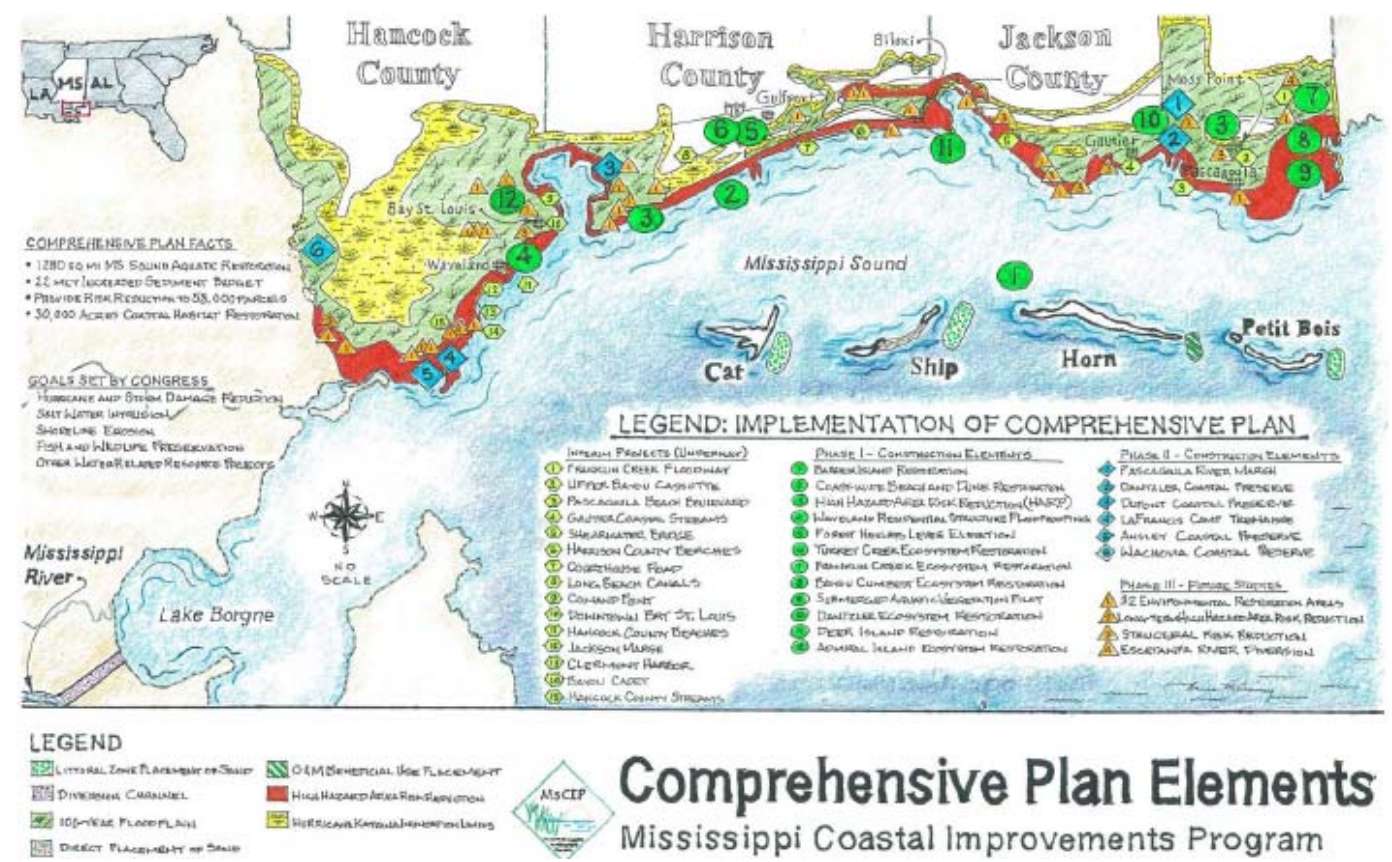

Comprehensive Plan Elements

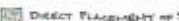

Mississippi Coastal Improvements Program

Figure 1. MsCIP Comprehensive Plan Elements (source: http://www.mscip.usace.army.mil).

The results of this exercise are summarized in Figure 3 in which the hurricanes are grouped in transport classes along the horizontal axis. The top plot shows that for lower transports the majority of the hurricanes (80\%) are classified in the Sallenger (2000) collision regime, some in the Sallenger (2000) overwash and inundation regimes. As the transports become larger (i.e. hurricanes become more energetic) the number of hurricanes in the inundation regime increases and for the three largest transport classes all hurricanes are in this regime. The somewhat discrete changes in the regimes are caused by the relative small number of hurricanes that induce the larger transports (see second plot). It can be seen that about $85 \%$ of the hurricanes $\left(2^{\text {nd }}\right.$ plot Figure 3 ) only contribute about $30 \%$ to the total hurricane transport load $\left(4^{\text {th }}\right.$ plot Figure 3$)$. Therefore, the transport contribution is determined with the MCC-model for the largest $15 \%$ (i.e. 32) of the hurricanes, representing approximately $70 \%$ of the 
hurricane transport load. As a consequence most tropical storms are excluded and milder hurricanes are only included if they make landfall in the vicinity of Ship Island (see Table 1). Larger hurricanes (H4 and $\mathrm{H} 5$ categories) making landfall at larger distances may induce a large enough effect to still be included (e.g. Lily, Rita and Ike).

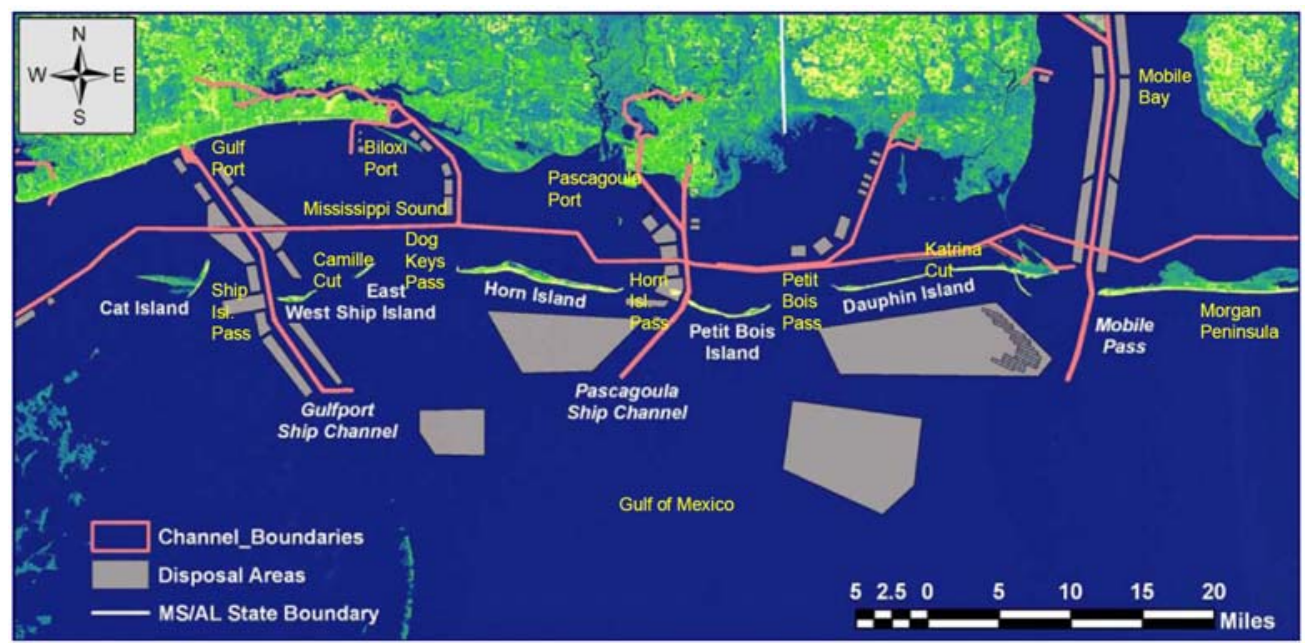

Figure 2. Overview of the Mississippi barrier islands, passes, channels and ports (source: Byrnes et al., 2012).

\section{LITTORAL TRANSPORTS}

The blue line in Figure 4 compares the averaged annual hurricane contribution (derived from the 1917-2010 period) with the annual transports for the averaged conditions (red line). Note that the total longshore transport caused by the hurricanes has been scaled by $1 / 0.72$ as $28 \%$ of the hurricane transport is ignored, see bottom plot Figure 3. Interestingly, the contribution of the hurricanes to the longshore transport along the Gulf oriented shorelines is of a similar order of magnitude as the contribution of the year-averaged waves. For Dauphin Island the contribution of the hurricanes to the long term longshore transport is slightly larger than that of the year-averaged conditions. However, along Petit Bois, Horn Island and Ship Island the contribution of hurricanes is overall somewhat smaller. The overall alongshore pattern of the hurricane transport is similar to that for the yearaveraged conditions, implying that the hurricanes tend to re-enforce erosive and accreting shoreline trends generated during year-averaged conditions.

The net longshore transports for the five hurricanes with the largest net contributions (bold in Table 1) at Ship Island are summarized in Figure 5 (again with the annual net transport for the averaged wave conditions shown as a reference). For the selected hurricanes the net transports are significantly larger or comparable to the annual transports for the averaged wave conditions. The unnamed 1947 hurricane and Georges (1998) result in the net largest longshore transport at Ship Island, which is primarily due to the proximity of the landfall locations. This is a consistent finding for the other hurricanes as well and is also causing the changes in the magnitude of the longshore transports between the islands (e.g. Ivan which make landfall at Fort Morgan peninsula and induces the largest longshore transports at Dauphin Island). The large longshore transports towards the western tip of the island are mainly caused by the currents flowing through the adjacent inlets and should be considered with care.

Interestingly, not all hurricanes induce a net westward transport at Ship Island, viz. Camille and Katrina result in significant eastward directed net transports at Ship Island but westward transports for the other islands. This was further investigated by separating the transports into a flooding phase (from the start of a hurricane to maximum surge level) and an ebbing phase (from maximum surge level to the end of a hurricane) for the five hurricanes shown in Figure 5. The net, flooding phase and ebbing phase transports are compared in Figure 6 for the 1947-hurricane and Katrina. Comparison of the net and gross transports for the selected hurricanes reveals that in most cases the gross transports are significantly larger than the net transports.

Analyzing the results of Camille and Katrina, Figure 5 reveals that, the magnitude of the transports varies both hurricanes but that transport patterns are very similar. It was found that at the Gulf-side of 
West Ship Island nearshore transports are dominated by the flooding phase, whereas further offshore ebbing is dominant (see also Figure 6). As both Camille and Katrina passed west of Ship Island along an approximately south-north track the ebb flows were enhanced by strong eastward winds as the hurricanes move north. For both hurricanes the emptying of Lake Ponchartrain and Lake Borgne primarily occurs through the inlets surrounding Ship Island causing the ebb phase to dominate over the flooding phase at Ship Island. This is confirmed by the water level gradients across Ship Island (Figure 7) which had the largest positive water level gradients (i.e. water level higher in Sound than in Gulf) across Ship Island for both hurricanes.
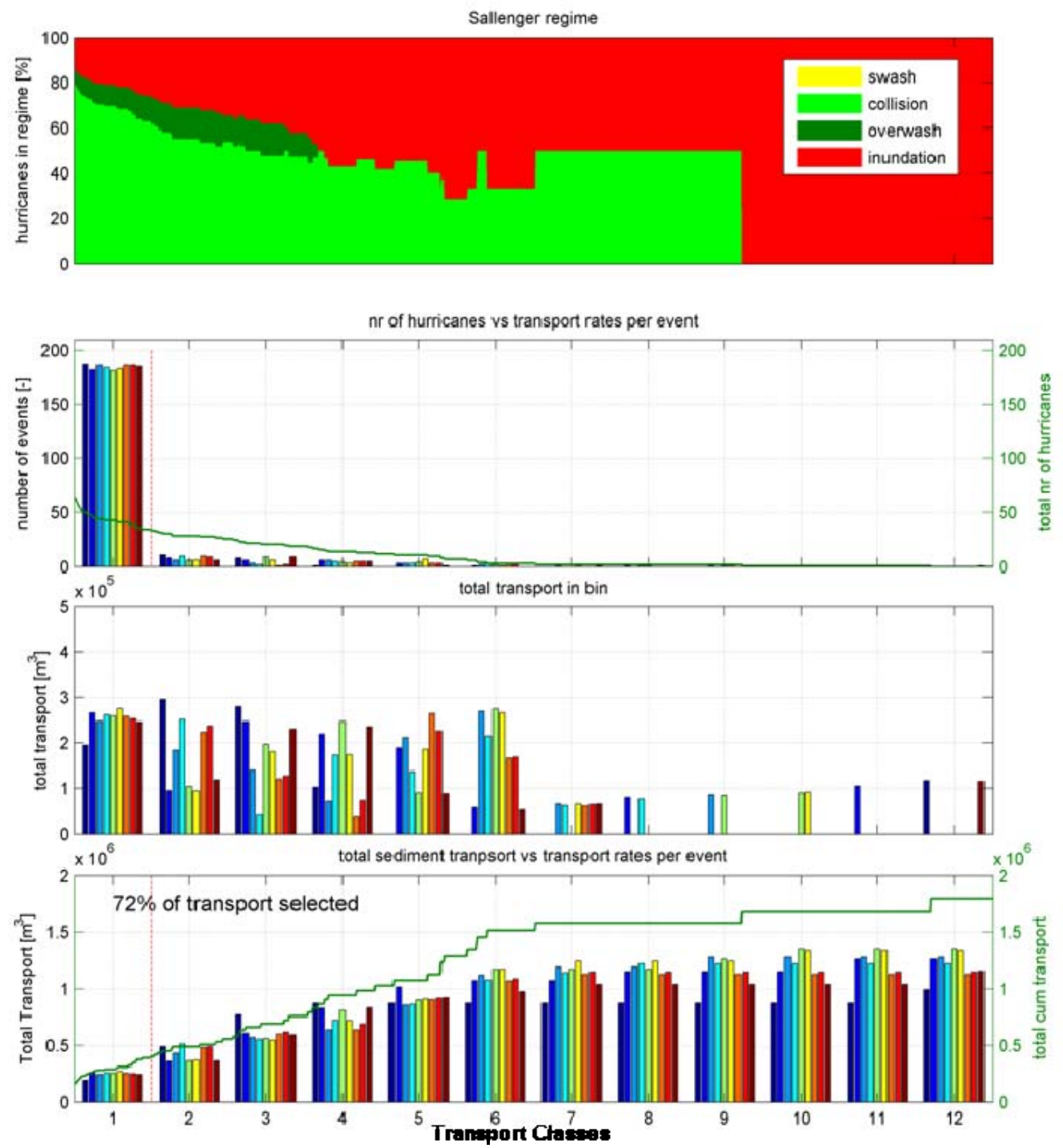

Figure 3. Summary of hurricane regimes and transport potential derived from large scale Delft3D-models at Ship Island, colors in histograms represent the different coastal orientations at Ship Island. 

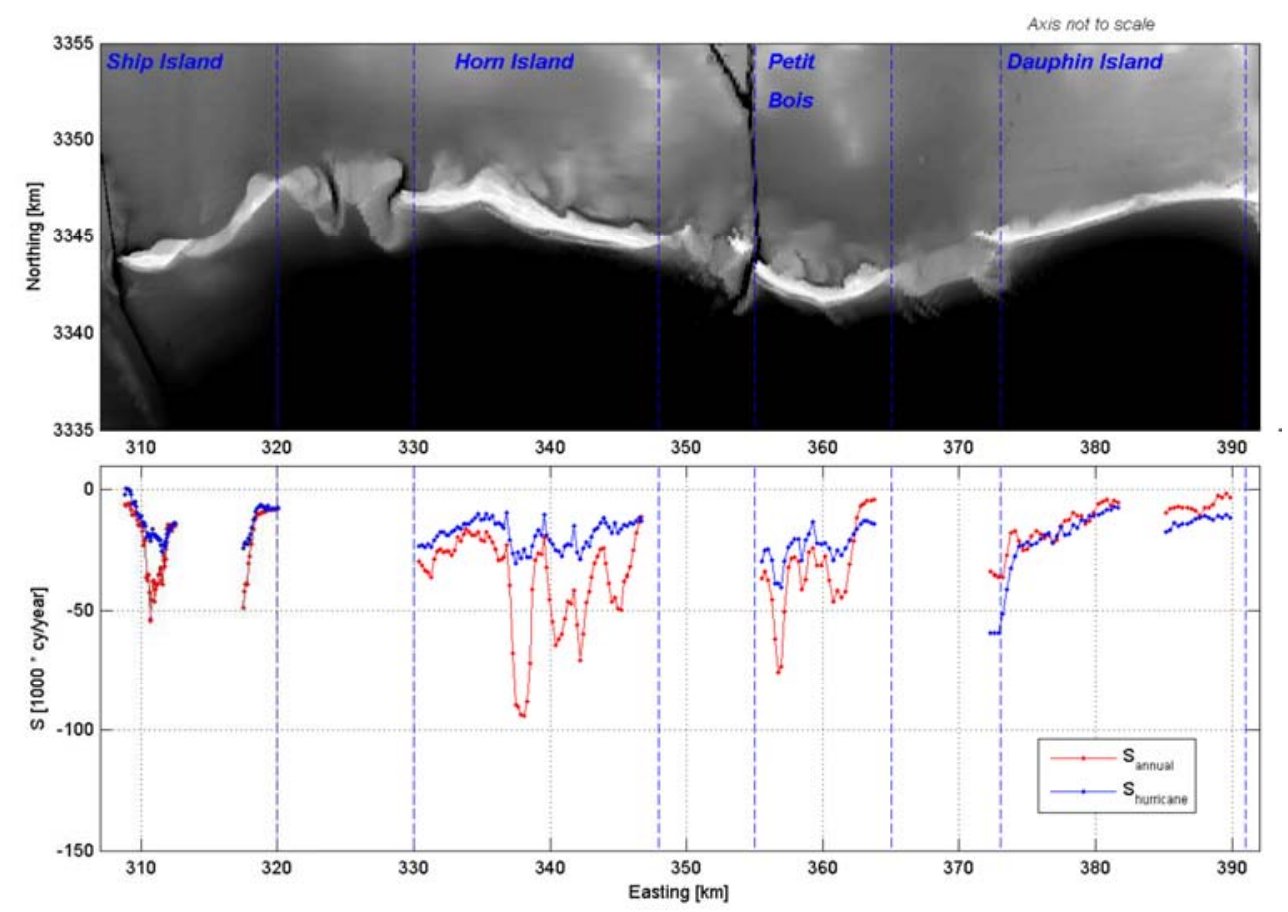

Figure 4. Scaled longshore transport due to hurricanes (blue) compared to annual transport due to yearaveraged conditions (red).

\begin{tabular}{|l|c|c|c|c|c|}
\hline \multicolumn{6}{|c|}{$\begin{array}{l}\text { Table 1. Hurricanes considered for transport calculation with MCC-model } \\
\text { (“H”: hurricane category, “TS”: tropical storm). }\end{array}$} \\
\hline Year/Month & Name & Category & Year/Month & Name & Category \\
\hline $1917-9$ & No Name & H4 & $1979-8$ & FREDERIC & H4 \\
$1918-8$ & No Name & H3 & $1985-8$ & ELENA & H3 \\
$1919-9$ & No Name & H4 & $1985-10$ & JUAN & H1 \\
$1920-9$ & No Name & H2 & $1985-11$ & KATE & H3 \\
& & & & FLORENC & \\
$1926-8$ & No Name & H3 & $1988-9$ & E & H1 \\
$1926-9$ & No Name & H4 & $1992-8$ & ANDREW & H5 \\
$\mathbf{1 9 4 7 - 9}$ & No Name & H5 & $1995-9$ & OPAL & H4 \\
$1950-8$ & BAKER & H3 & $1997-7$ & DANNY & H1 \\
& & & & GEORGE & \\
$1953-9$ & FLORENCE & H3 & $\mathbf{1 9 9 8 - 9}$ & S & H5 \\
$1955-7$ & BRENDA & TS & $2002-9$ & ISIDORE & H3 \\
$1960-9$ & ETHEL & H5 & $2002-9$ & LILI & H4 \\
$1964-9$ & HILDA & H4 & $\mathbf{2 0 0 4 - 9}$ & IVAN & H5 \\
$1965-8$ & BETSY & H5 & $\mathbf{2 0 0 5 - 8}$ & KATRINA & H5 \\
$\mathbf{1 9 6 9 - 8}$ & CAMILLE & H5 & $2005-9$ & RITA & H5 \\
$1974-8$ & CARMEN & H4 & $2008-8$ & GUSTAV & H4 \\
$1979-7$ & BOB & H1 & $2008-9$ & IKE & H4 \\
\hline
\end{tabular}

For the unnamed 1947 hurricane the ebbing phase is found to be relatively unimportant (no positive mean water level gradients, see Figure 7) causing the net transport patterns to be dominated by the flooding phase. As this hurricane crossed the Chandeleur Islands about $80 \mathrm{~km}$ South of Ship Island along an East-west track, the flooding was enhanced by the prevailing wind directions being predominantly westward and northward directed as it passes the MCC and moves further westward, respectively. The ebb flows are therefore not being accelerated by the hurricane winds resulting in relatively low transports during the ebbing phase. The opposite was the case for Katrina where ebb 
surges were locally dominant (compare bottom plots in Figure 6 showing the ebb surge induced transports for the 1947-hurricane and Katrina).

Georges (1998) passed just East of Ship Island causing the second largest net longshore transports at Ship Island of the considered 32 hurricanes. As surge levels in Lake Ponchartrain were significantly lower compared to Katrina and Camille, the ebb phase resulted in relatively low transports. The fact that the (westward) transports during the flooding phase were found to be significantly larger for Katrina (middle plot in Figure 6) compared to Georges (not shown) highlights the importance of separating both phases and the large potential impact of the ebbing phase on the net transports.

The sediment transport along the Sound side of the islands is usually significantly lower than the Gulf side, but is still of relevance for the sediment budget (discussed furtheron). Furthermore, the hurricanes have the ability to mobilize and induce significant transports through the inlets as well (as is obvious from Figure 6). The net transport direction mainly depends on the characteristics of the hurricane and may also vary from inlet to inlet. For example, the relatively deep area just north of the western tip of West Ship Island is likely to be maintained by the hurricane induced ebb flows. Furthermore, only the ebb flows (and the associated wave action) have the capacity to induce major changes to Cat Island. Consequently, the spit at the northern tip of Cat Island (see Figure 11) is probably the result of hurricane generated ebb flows.

A limited analysis of the model results for the ebbing phase is presented in Figure 8 for hurricane Ivan and Katrina, highlighting the relevance of the hurricane track as this is the determining factor for the associated winds and waves to amplify or damp the hurricane ebb flows. As hurricane Ivan passed East of Ship Island the maximum ebb flows coincide with high winds and (wind generated) waves in approximately the same direction (left column of plots in Figure 8). This results in relative high waves $\left(\mathrm{H}_{\mathrm{s}}\right.$ is approximately 1.5 to $\left.2 \mathrm{~m}\right)$ at the Sound side of Ship Island which will results in significant transports around the western tip of West Ship Island. For Katrina even stronger ebb flows are present, but as Katrina passed West of Ship Island the wind and (wind-generated) waves are still landward directed resulting in significantly lower waves at the Sound shoreline of West Ship Island. However, the Gulf side of the island is experiencing high waves and ebb flows resulting in significantly enhanced eastward directed transports (right column of plots Figure 8).

\section{SEDIMENT BUDGET}

\section{Comparison with survey data based sediment budget}

First, the sediment budget study of Byrnes et al. (2012) is considered. In this study, which is based on historical shoreline and bathymetric survey data over a period of about 90 years between 1917 and 2010 sediment transports were derived from observed volume changes (corrected for dredging) between consecutive surveys. In Figure 9, the MCC-model results are compared with the macro-scale sediment budget of Byrnes et al. (2012). Byrnes considers 5 boxes for which the sediment exchange with the surrounding area including the Gulf and sound side of the islands and offshore was determined. Here focus on the longshore transport above the $-30 \mathrm{ft}(\sim 10 \mathrm{~m})$ depth contour. The Byrnes study clearly shows that for boxes 1 to 3 the littoral transport over the box edges is substantially larger than the sediment losses offshore and to the sound. However, in boxes 4 and 5 the littoral transport rapidly decreases whereas cross-shore sediment losses offshore and to the sound increase. According to the Byrnes sediment balance, at the eastern edge of box 1, the littoral transport is about 300,000 $\mathrm{cy} / \mathrm{yr}$.

At the western edge of box 1, the littoral transport increases to more than $400,000 \mathrm{cy} / \mathrm{yr}$ and remains more or less constant until the western edge of box 3. From here to the west, the littoral transport decreases to zero at the western boundary of box 5. Compared to the modeled transports, the magnitude of the littoral transport estimated by Byrnes is substantially larger. However, some differences between the model results and the sediment balance of Byrnes are to be expected. The study of Byrnes covers a period of 90 years during which substantial island and bed level changes have occurred (e.g. . islands have rotated, migrated westward and complete islands have disappeared) whereas the modeled sediment transports are based on a single recent bathymetry without assuming any change. Especially, the channels in the inlets were re-aligned, deepened and widened, which has reduced the sediment exchange between the barriers. As a result it is likely that in this period also the longshore transport along the barriers has reduced, due to adaptation of the barrier shape and orientation to the reduced bypass. Therefore the average transport over the last 90 years is likely to be larger than for the present situation. 

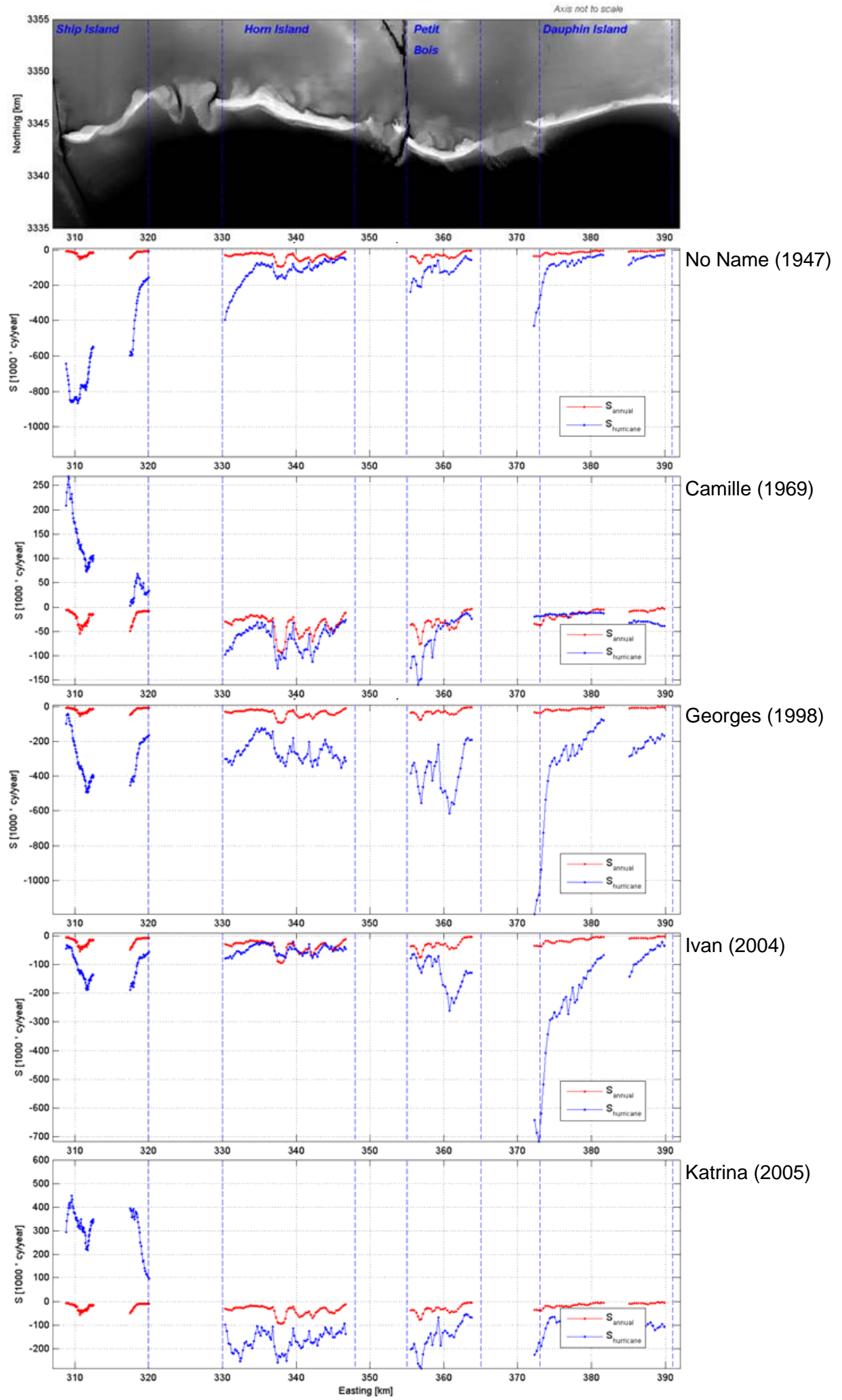

Figure 5. Averaged conditions (red) and hurricane (blue) induced net longshore sediment transports. 

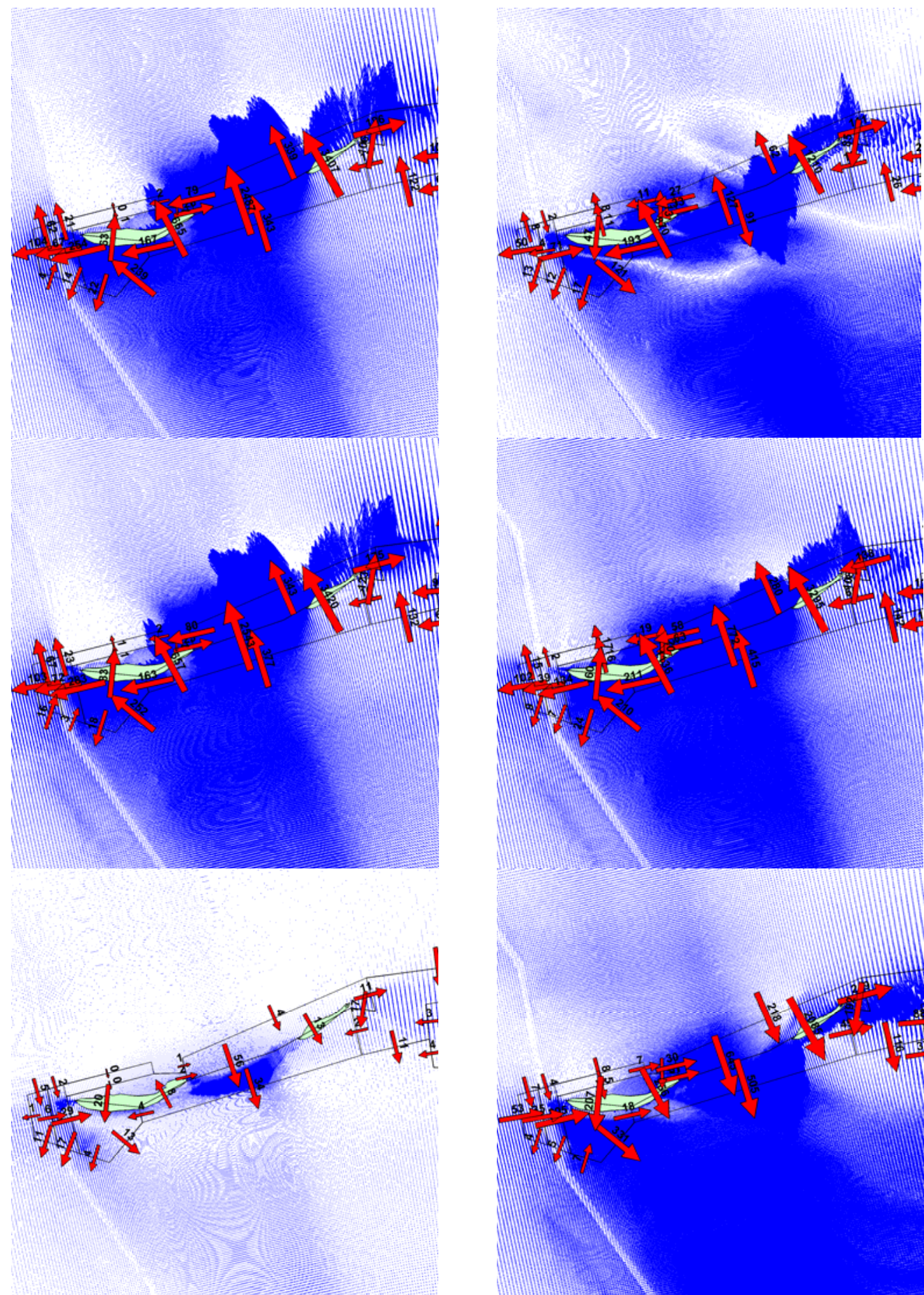

Figure 6. Transports (1000*cy/yr) for hurricane 1947-No Name (left column) and Katrina-2005 (right column) Top plot: net transports, Middle plot: averaged transports during flooding phase, bottom plot: averaged transports during ebbing phase (red arrows indicate integrated transports through the sections, blue vectors mean modeled transports for the indicated period). 


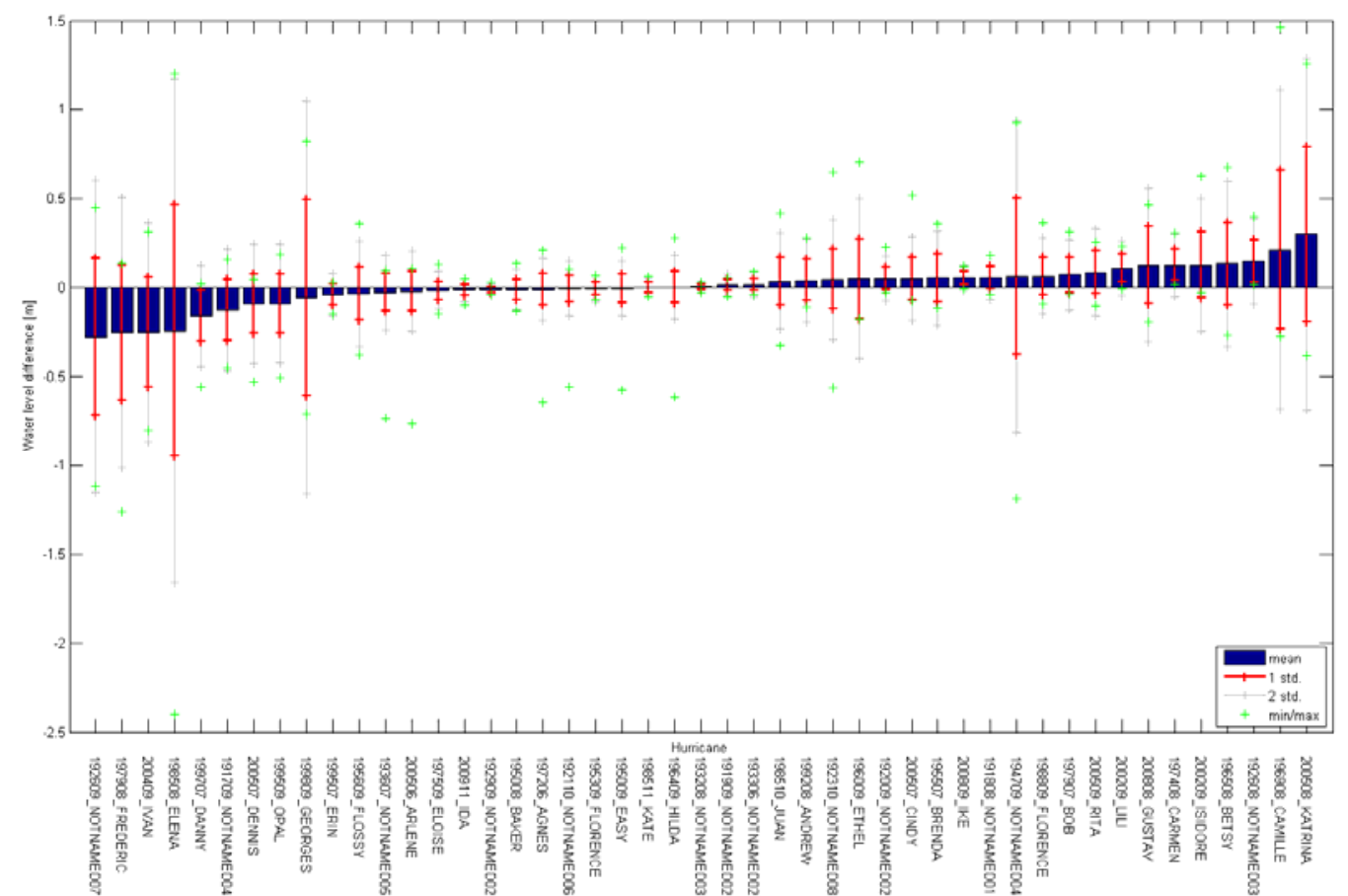

Figure 7. Time-averaged water level differences across Ship Island derived from the MCC-model. Standard deviations are obtained from the $\mathbf{7 2}$ hours around the peak of the storm.
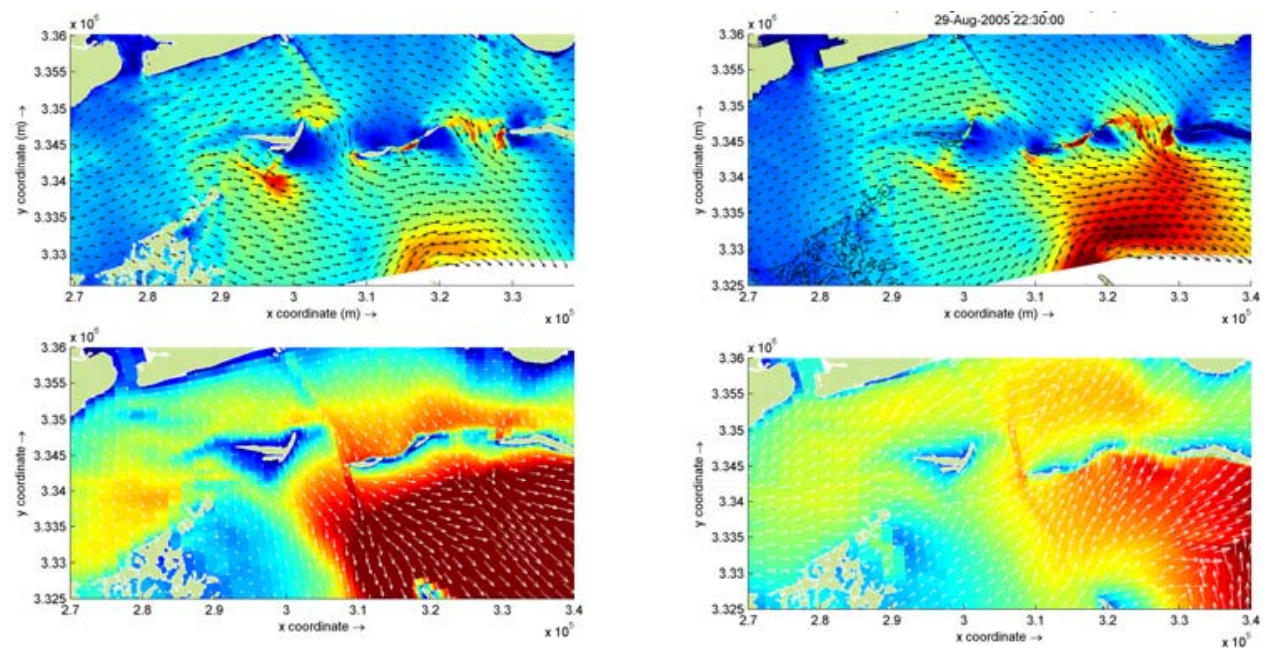

Figure 8. Velocities (top row) and wave heights and direction (bottom row) for Hurricanes Ivan (left column) and Katrina (right column) during maximum ebb flows (relative color scale, red = high velocity/wave height, blue $=$ low velocity/wave height)

To relate the large scale longshore transports to morphological changes, the gradients in longshore transports are compared in Table 2. Note that only the volume changes based on gradients in the longshore transport generated along the Gulf shores is taken into account. The present volumes changes indicate that on a large scale and in a qualitative sense the computed gradients are in fair agreement (more or less within a factor 2). Only box 4 deviates considerably which also happens to be the area that experienced dramatic morphological changes over the past century as Dog Island completely disappeared at what is now Dog Keys Pass (i.e. the inlet between Horn Island and East Ship Island).

The MCC-model results for year-averaged and hurricane conditions (excluding cold fronts) have also been compared with more detailed sediment balances by considering areas approximately similar to the accretion and erosion areas presented by Byrnes et al. (2012) in Figure 10. The MCC-model 
volume changes are derived from the computed net transports across the boundaries assuming no bed change. Qualitatively the overall erosion-accretion patterns computed with the model are in fair agreement with the pattern presented by Byrnes. At the western end of Dauphin Island (area 1) the model and Byrnes both indicate accretion. But Byrnes indicates a considerably higher accretion rate than the model. This may be (partly) due to the fact that the Byrnes balance includes the effect of the migration of the island into this area which may not only affect the longshore transport at Dauphin Island, but also the balance of Petit Bois Pass. This is illustrated by the balance of area 2, where the model shows considerable accretion in the area where further migration of Dauphin Island is expected in the future. For the balance areas 1 and 2 combined, the computed accretion is in fair agreement with the balance of Byrnes.

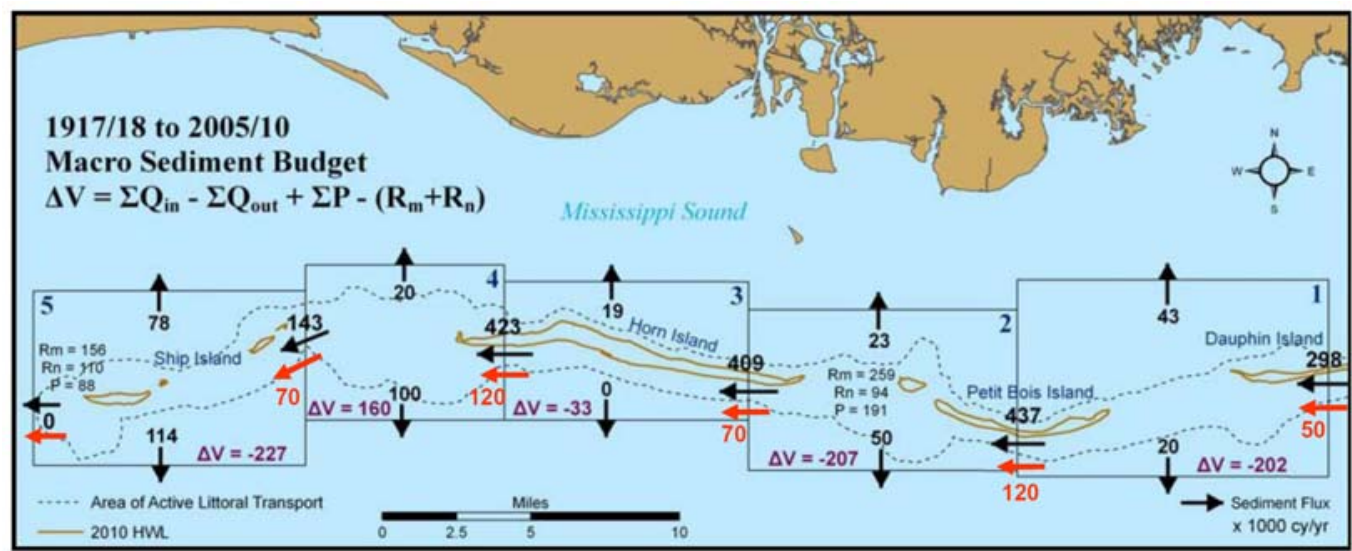

Figure 9. Comparison of model the simulated and survey based macro scale sediment budgets (after Byrnes et al., 2012: black arrows and numbers, simulated with Delft3D-MCC: red arrows and numbers, all in cy/year).

\begin{tabular}{|c|c|c|}
\hline \multicolumn{4}{|c|}{$\begin{array}{l}\text { Table 2. Comparison of volume changes (cylyear) due to gradient in } \\
\text { longshore transports across the boxes indicate in Figure 9. }\end{array}$} \\
\hline Box & Byrnes et al. (2012) & Modeled \\
\hline 1 & $-143,000$ & $-70,000$ \\
2 & $+57,000$ & $+50,000$ \\
3 & $-33,000$ & $-50,000$ \\
4 & $+260,000$ & $+50,000$ \\
5 & $+143,000$ & $+70,000$ \\
\hline
\end{tabular}

Along Petit Bois Island (balance areas 3 and 4) the computed pattern is similar to that presented by Byrnes. However, in area 4 the computed accretion is considerably smaller than the rate presented by Byrnes. This may be explained in a similar way as discussed above for balance area 1. For balance area 5 the model indicates some accretion, where Byrnes indicates erosion. Balance area 5 represents the Pascagoula Ship Channel. Byrnes factored in the removal of dredged material from the navigation channel however such dredging actions were not simulated in the model. The computed accreting tendency in this area is as to be expected for the present situation.

In the areas 6 and 7 in Horn Island Pass the computed accretion and erosion are in fair agreement with the balance presented by Byrnes. Along Horn Island the computed accretion and erosion pattern (areas 8,9 and 10) is in fair agreement with the Byrnes balance, though overall the computed values are somewhat smaller. In areas 11 and 12 in Dog Keys Pass the model indicates similar to Byrnes accretion respectively erosion, though with considerably smaller rates than Byrnes. It is not clear how the temporary existence of Dog Island has affected the long term balance of Byrnes, but the dynamics of this island may have contributed to relatively large volume changes derived from the maps and surveys.

The computed accretion and erosion along East Ship Island and Camille Cut (areas 13 and 14) are in reasonable agreement with that presented by Byrnes. The areas 15 and 16 combined and area 17 show a fair similarity between the computed accretion and that presented by Byrnes. Balance area 18 is located at the present Ship Island navigation channel location, after re-alignment of the channel around 1993. Until that time, this section of the channel was located more eastward. In the Byrnes balance, in 
area 18 a tendency of erosion is indicated, while with the present navigation channel in place sedimentation occurs in this area. The model shows a more or less neutral balance, but it is noted that the balance of this complex area depends largely on the exact position of the balance boundaries, since small shifts may change the balance considerably. The model indicates that area 19 is slightly erosive, while Byrnes indicates some accretion. However, also this small area is very sensitive to the exact position of the area boundaries. In addition, Byrnes factored in the removal of dredged material from the navigation channel in area 18 as well as the associated dredged material placement in area 19; however, such dredging actions were not simulated in the model.
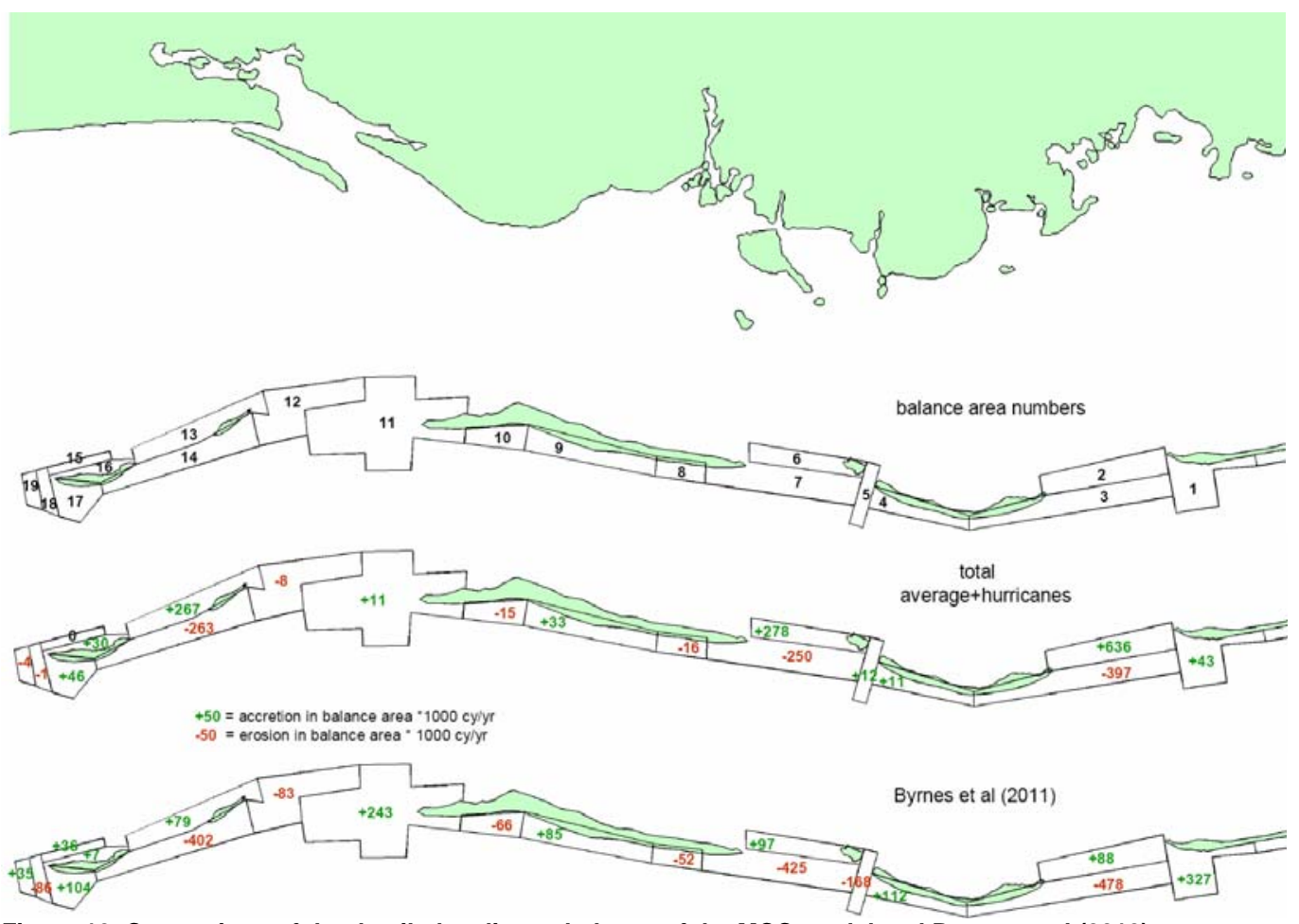

Figure 10. Comparison of the detailed sediment balance of the MCC-model and Byrnes at al (2012).

\section{Comparison with dredging volumes}

Although more channels intersect the MCC littoral system focus here is on the Gulfport Ship Channel (located west of Ship Island), which runs through Ship Island Pass as it is the closest to the primary area of interest (Figure 11). The maintenance dredging records for the passes is shown in Figure 12. Unfortunately, the composition of the dredged material (i.e. percentage sand and silt) is unknown. About 43,000 cy/yr was dredged over a channel length of about 4,000 ft between 1900-1950 (see Figure 11). The recent dredging volumes which are representative for the period after realignment of the channel to the west in 1992 is about 175,000 cy/yr over an assumed channel length of 8 miles.

Changes in the dredging rates can partly be attributed to manmade modifications to the channel cross-section (deepening and widening of the channel), and partly to changes in the length of the dredged channel section. For example, it is our understanding that for Ship Island Pass the sudden increase in dredging quantities in 1950 is not only due to the deepening of the channel, but is also caused by extension of the dredged channel section from $4,000 \mathrm{ft}$ to 8 miles. In the 8 miles long channel section a considerable part of the sedimentation can originate from other sources than the littoral drift. This may affect the sediment composition (e.g. increased fraction of fines) and also the tide and hurricane contributions may become relatively more important. No data was available on the distribution of the dredging volumes along the 8 miles section. It is remarkable that there are several periods longer than 10 years in which no or negligible maintenance dredging was required. 


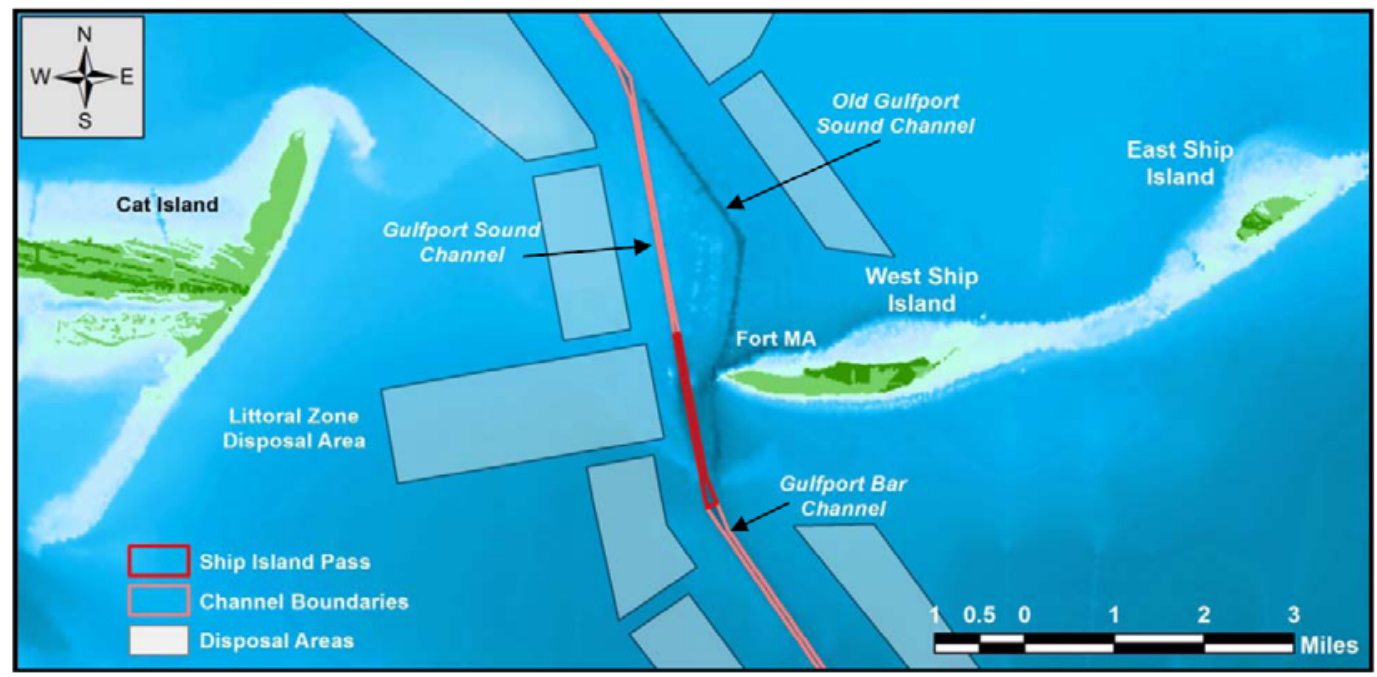

Figure 11. Locations of Ship Island Pass and the disposal areas (source: Byrnes et al., 2012).

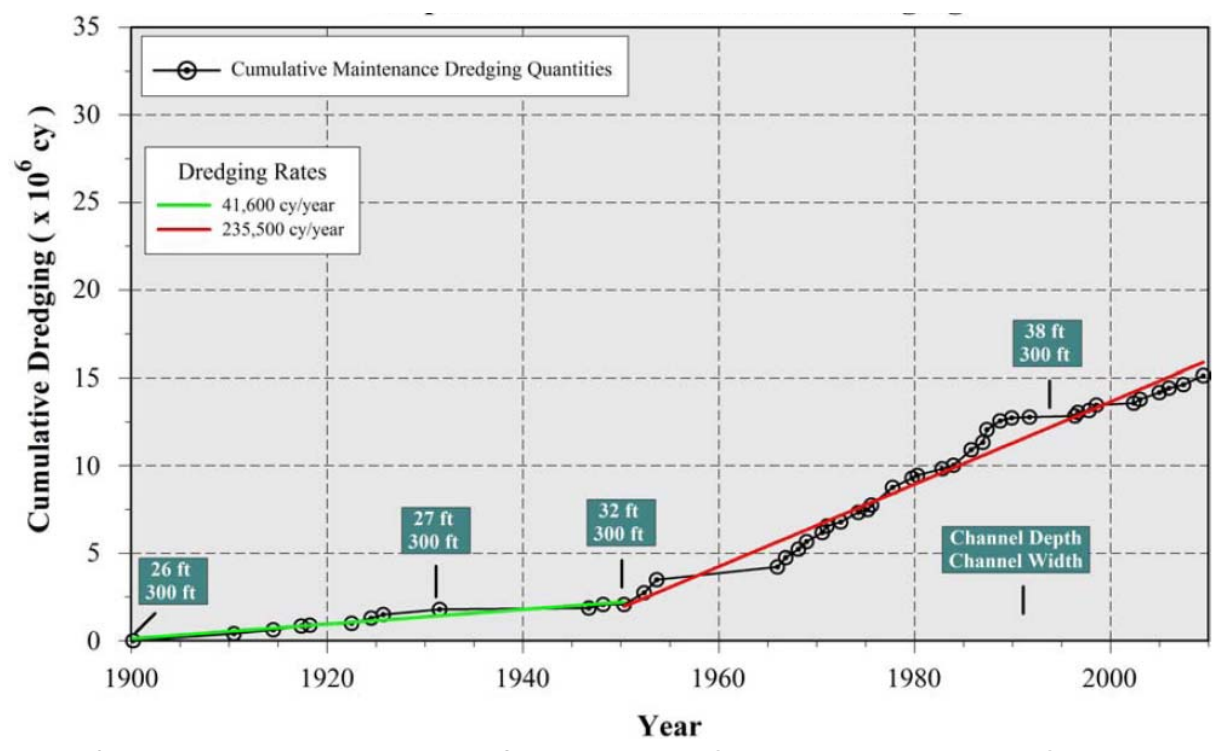

Figure 12. Cumulative dredging volumes at Ship Island pass (source: Byrnes et al., 2012).

Given the considerations above, it is likely that a substantial part of the dredged material for the bar channel since 1950 originates from other sources than the littoral drift along the barrier islands. In the period 1900-1950 dredging was carried out over a length of 4,000 ft, which approximately coincided with the width of the littoral zone. In that period the average dredging rate was about 40,000 cy/yr. Given the uncertainty on the distribution of the dredging along the channel and the composition of the dredged material, the sedimentation for sand was assumed to be in the range of 40,000 to 180,000 $\mathrm{cy} / \mathrm{yr}$ for the littoral zone. Byrnes et al. (2012) estimated the rate of material dredged from the littoral zone to be $156,000 \mathrm{cy} / \mathrm{yr}$. Also note that the estimated rate of placement of dredged sandy material in the littoral zone to the west of the channel was 76,000 cy/yr. The dredged sandy material has typically been placed in the littoral zone site and the fine grain sediment taken to an ocean dredged material disposal site (ODMDS). For the entire 8 miles dredging zone (i.e. pass and outer bar), the upper limit of the sedimentation of sand is estimated at 180,000 cy/yr (based off of dredging records since the realignment in 1993).

As the MCC-model is not considering bed change, the shoaling volumes are derived from the transports across the indicated balance boundaries (approximately along the top of the channel slopes, see Figure 13). However, the integrated transport rates are sensitive to the exact location of the area boundaries due to the relatively low resolution. This prevented distinguishing between the channel 
floor and slopes. Therefore, the gross volume change (i.e. transport towards the balance areas) and the net volume change are both considered. The former is the upper limit and the latter the lower limit of the actual trapping rates (i.e. the gross volume change would be the sedimentation in case of $100 \%$ sand trapping).

In Table 3 the comparison of the dredging volumes with a number of possible sources are separately considered. The averaged conditions have a similar contribution compared to the hurricanes for area 1. However, as the hurricanes mobilize the bed at much larger water depth and cause large flows through the inlet the contribution for area 2 is substantially larger. The effects of cold fronts (due to transports originating along the northern shores of the island) is smaller but can not be ignored. Furthermore, no additional sedimentation caused by the disposal areas just west of the channel could be identified. The total computed sedimentation is smaller than the dredging rates, but is still deemed acceptable given the uncertainties in the model (discussed in the following section) and the data (e.g. sediment composition).

\begin{tabular}{|c|c|c|c|c|}
\hline & \multicolumn{3}{|c|}{ Table 3. Computed annual sedimentation rate in balance area. } \\
\hline \multirow{2}{*}{ Condition } & \multicolumn{2}{|c|}{$\begin{array}{c}\text { Balance area 1 } \\
\text { (littoral zone) }\end{array}$} & $\begin{array}{c}\text { Balance areas 1 + } 2 \\
\text { (8 miles zone) }\end{array}$ \\
\hline & $\begin{array}{c}\text { Gross } \\
\text { (cy/yr) }\end{array}$ & $\begin{array}{c}\text { Gross } \\
\text { (cy/yr) }\end{array}$ & $\begin{array}{c}\text { Net } \\
\text { (cy/yr) }\end{array}$ \\
\hline year-averaged & $15,000^{*}$ & $10,000^{*}$ & $20,000^{*}$ & $15,000^{*}$ \\
\hline hurricanes & 20,000 & 10,000 & 80,000 & 40,000 \\
\hline cold fronts & 5,000 & 5,000 & 5,000 & 5,000 \\
\hline disposal area & nihil & nihil & nihil & nihil \\
\hline total & 45,000 & 25,000 & 105,000 & 60,000 \\
\hline Dredged & \multicolumn{2}{|c|}{$40,000-180,000$} & & 180,000 \\
\hline
\end{tabular}

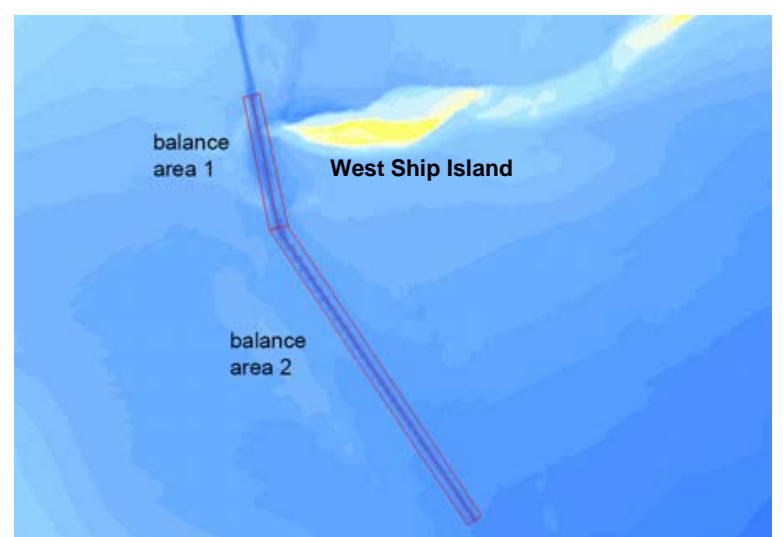

Figure 13. Considered balance area for channel sedimentation assessment, littoral zone (area 1) and 8 miles zone (areas 1 + 2).

\section{UNCERTAINTIES IN MODEL PREDICTIONS}

Numerical models require many input parameters and Delft3D is no exception. A detailed sensitivity analysis is presented in which the parameters are varied to which the model is potentially most sensitive. Both physical parameters (e.g. grain size or salinity) and model parameters (e.g. choice of transport formulation or bed shear stress formulation) are considered. Both the model parameters and the physical parameters are varied within the appropriate ranges for the study area. The parameters are subdivided into four groups for which the longshore transports along the barrier island are evaluated (default settings are underlined):

- Group A: Hydrodynamics

o Bed shear stress formulation under waves (Fredsoe, 1984; Van Rijn, 2007)

o Density $(\rho)$, salinity $(\mathrm{S})$ and temperature $(\mathrm{T})$ of the sea water $\left(1025 \mathrm{~kg} / \mathrm{m} 3,31 \mathrm{ppt}, 15^{\circ} \mathrm{C}\right.$; $\left.1020 \mathrm{~kg} / \mathrm{m} 3,31 \mathrm{ppt}, 30^{\circ} \mathrm{C} ; 1000 \mathrm{~kg} / \mathrm{m} 3,10 \mathrm{ppt}, 30^{\circ} \mathrm{C}\right)$

o Background diffusivity and viscosity $(\underline{0.5,0.5} ; 0.2,0.2 ; 1,1)$ 
- Group B: Wave conditions

o Breaker parameter ( $\gamma=0.73$; Ruessink, 1998; Battjes and Stive, 1985):

o Increase of $10 \%$ of all wave heights

- Group C: Sediment properties

o Median sediment grain size $(\mathrm{D} 50=200,250, \underline{300}, 400 \mu \mathrm{m})$ :

- Group D: Sediment transport formula

O Van Rijn (1993)

o Van Rijn (2007)

The results of the sensitivity analysis are shown as transport envelops for each group in Figure 14. Group A only has a minor effect on the magnitude of the alongshore sediment transport rates and hardly impacts the overall alongshore patterns (i.e. the spatial trends and gradients remain more or less the same). Also Group B had a relatively small effect as the overall patterns did not change. However, both the sediment properties (Group C) and the sediment transport formula (Group D) have a dramatic impact on the computed sediment transports. A larger D50 increases the critical shear stress of the sediment at which the grains may become suspended and increases the particle fall velocity. Under the same hydrodynamic conditions this results in decreased mobility of the sediment (i.e. decreasing sediment transport rates). Although both the Van Rijn (1993) and (2007) sediment transport formulations are widely applied in sediment transport modeling, the differences in the alongshore sediment transport rate are large.

Based on the outcomes of the sensitivity analysis a range of 50 to $200 \%$ on the default transports seem appropriate. However, the longshore transport distribution patterns are mostly unaffected which implies that only the response rates are affected, not the morphological response itself.

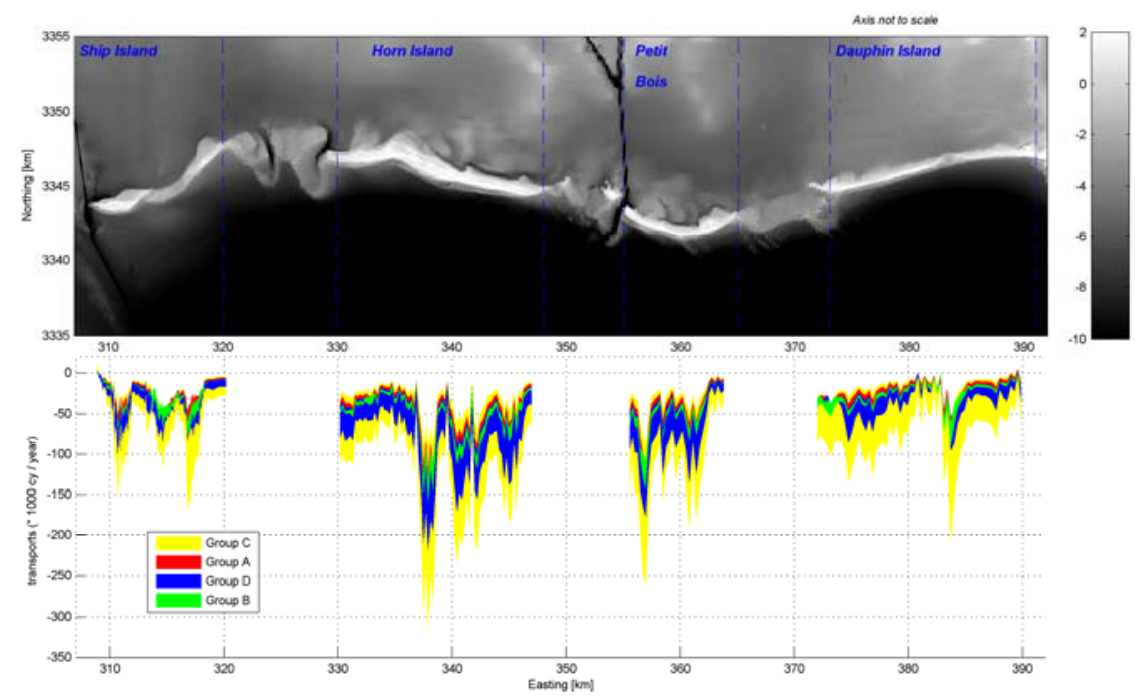

Figure 14. Envelope of longshore transports due the variations in each of the groups.

\section{CONCLUSIONS}

Numerical modeling was undertaken to obtain insight into the sediment balance of the Mississippi Barrier Islands (Dauphin Island, Petit Bois, Horn Island and Ship Island). Such modeling provides a basis for more detailed studies on the impacts of the Ship Island restoration efforts (i.e. the closure of Camille Cut and the nourishments at West and East Ship Island). Contributions to the sediment balance were assessed for year-averaged conditions, hurricanes and cold fronts.

For the long term average net longshore transport along the southern shorelines of the barriers (i.e. exposed to the Gulf of Mexico), the contribution of year-averaged conditions and hurricanes are of similar order of magnitude, although the mean annual percentage occurrence of hurricanes is no more than about 3\%. Along the northern shores (Mississippi Sound side) the transport is considerably smaller and the contributions of cold fronts and hurricanes to the sediment transports are more or less equal.

For the year-averaged conditions a westward directed net transport is found. The net effect of the historic hurricanes is also a westward directed transport. It is remarkable that for some hurricanes (e.g. 
Camille and Katrina) the net transport along Ship Island was directed eastward, while at all other barrier islands the evaluated hurricanes resulted in a net westward transport. This can be explained by the relatively strong ebb flows around Ship Island. This implies that, depending on the hurricane characteristics, ebb flows can have a larger effect than the build-up (flooding) phase of a hurricane. Therefore, ebb flows have the potential to substantially exacerbate the morphological response at Ship Island.

For all islands except Ship Island the computed net longshore transport at the western end is larger than the transport at the eastern end. This would indicate overall erosion of the Gulf-orientated shorelines, which is confirmed by observations. Moreover, the computed longshore transport pattern along all barriers can be explained by the individual island geometries, and at most locations observed shoreline behavior seems to confirm the computed pattern. For all islands the net transport at their eastern end is somewhat smaller than the net transport at the western end of the updrift (eastward) located island. This may be an indication that a significant part of the sediment is not bypassing the passes to feed the next island in the chain. This phenomenon is evident at both maintained and unmaintained inlets in the system.

The overall effect of the year-averaged conditions and the hurricanes at the Gulf side of the islands is a net westward directed transport with a computed magnitude varying between 10,000 and 120,000 cy/yr. At the Sound side the computed net transport is less than 10,000 cy/yr. Given the uncertainties in the predicted longshore transports a range of $50 \%$ to $200 \%$ should be applied. The long-term sand balance presented derived from surveys and dredging record by Byrnes et al. (2012) are in the same range as the computed large-scale sediment balance of the MCC if the uncertainty is considered. Furthermore, the computed erosion and accretion patterns show a good overall qualitative agreement. However, at some locations the quantitative resemblance is poor. The main sources of error are that the modeling only considered the post-Katrina bathymetry and that bed changes were ignored (i.e. only initial transports were calculated).

\section{ACKNOWLEDGEMENTS}

The bathymetry data incorporated in the presented modeling effort was kindly provided by A.

Sleath Grzegorzewski and T. Wamsley from USACE-ERDC-CHL.

\section{REFERENCES}

Byrnes, M.R.; Rosati, J.D.; Griffee, S.F., and Berlinghoff, J.L., 2012. Littoral Sediment Budget for the Mississippi Sound Barrier Islands. Technical Report ERDC/CHL TR-12-xx. Vicksburg, MS: U.S. Army Engineering Research and Development Center, Vicksburg, MS, 180p.

Lesser, G.R., Roelvink, J.A., van Kester, J.A.T.M. and Stelling, G.S., 2004. Development and validation of a three-dimensional morphological model. Coastal Engineering 51 (8-9), 883-915. doi:10.1016/ j.coastaleng.2004.07.014.

Rosati, J.D., Byrnes, M.R., Gravens, M.B., Griffee, S.F., 2009. Mississippi Coastal Improvement Project Study, Regional Sediment Budget for Mississippi Mainland and Barrier Island Coasts, July 2009.

Sallenger, A.H., 2000. Storm impact for barrier islands. Journal of Coastal Research, Vol. 16, No. 3, 890-895.

Van Rijn, L.C., Walstra, D.J.R. and van Ormondt, M., 2007. Unified view of sediment transport by currents and waves. IV: Application of morphodynamic model. Journal of Hydraulic EngineeringASCE 133 (7).

USACE, 2009a. Comprehensive Plan and Integrated Programmatic Environmental Impact Statement, Mississippi Coastal Improvements Program (MsCIP) Hancock, Harrison, and Jackson Counties; Comprehensive Plan and Integrated Programmatic Environmental Impact Statement. Volume 1: Main Report, June 2009.

USACE, 2009b. Mississippi Coastal Improvement Program (MsCIP) Hancock, Harrison, and Jackson Counties, Mississippi. Appendix H, Barrier Islands, June 2009. 